\title{
PREPARATION AND STABILITY EVALUATION OF LL-37 CREAM
}

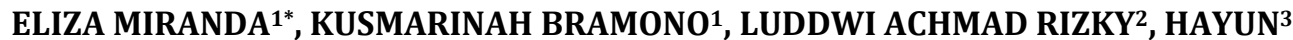

${ }^{1}$ Department of Dermatology and Venereology, Faculty of Medicine, Universitas Indonesia, Depok, Indonesia, ${ }^{2,3}$ Faculty of Medicine, Universitas Indonesia, Depok, Indonesia

Email: mirandaeliza74@gmail.com

Received: 04 Sep 2020, Revised and Accepted: 03 Sep 2021

\section{ABSTRACT}

Objective: The present study aimed to prepare LL-37 in a cream formulation (0/W emulsion) and evaluate its stability by determining the physical changes in the cream and concentration of LL-37 using validated high-performance liquid chromatography:

Methods: The method was conducted at room temperature using a C18 column ( $5 \mu \mathrm{m} \times 250 \mathrm{~mm} \times 4.6 \mathrm{~mm})$ as a stationary phase, a mixture of $0.1 \%$ trifluoroacetic acid (TFA)/water (A) and 0.1\% TFA/acetonitrile (B) (85:15) as the mobile phase, a flow rate of $1.0 \mathrm{~mL} / \mathrm{min}$, an d photodiode array set at $228 \mathrm{~nm}$ as the detector. The method was validated in compliance with the Association of Official Analytical Chemists and International Conference on Harmonization guidelines. It demonstrated excellent linearity, accuracy, precision, specificity, the limit of detection, and limit of quantitation.

Results: The chromatographic analysis indicated minimal degradation of LL-37 during the 12-week, with a predicted expiry time of 99 and 75 mo stored at $4{ }^{\circ} \mathrm{C}$ and $28^{\circ} \mathrm{C}$, respectively.

Conclusion: LL-37 cream establishes good physical characteristics and stabilizes the active ingredient, especially at $4{ }^{\circ} \mathrm{C}$ and $28{ }^{\circ} \mathrm{C}$ storage. Therefore, the emulsion delivery system of LL-37 cream is harmless and stable as a novel alternative vehicle of LL-37.

Keywords: LL-37, Cream, High-performance liquid chromatography, Stability

(C) 2021 The Authors. Published by Innovare Academic Sciences Pvt Ltd. This is an open access article under the CC BY license (https://creativecommons.org/licenses/by/4.0/) DOI: https://dx.doi.org/10.22159/ijap.2021v13i6.39639. Journal homepage: https://innovareacademics.in/journals/index.php/ijap

\section{INTRODUCTION}

Diabetic foot ulcer (DFU) is one of the major complications resulting from diabetes. The prevalence of the disease worldwide is estimated at $6.3 \%$ [1]. The treatment of DFU is still challenging and often achieves unsuccessful outcomes. Infection control, pressure relief, wound debridement, and revascularization are the main principles of DFU management [2]. Numerous studies have been conducted to evaluate several therapeutic agents' promising effects, including an antimicrobial peptide released upon wounding, LL-37, in treating DFU. LL-37 originates from the $18 \mathrm{kDa}$ human cathelicidin antimicrobial protein (hCAP18) [3].

The upregulation of hCAP18/1L-37 expression occurs within several hours after acute wounding, and the protein is released toward the wound edges through basal epidermal keratinocytes [4]. However, although hCAP18 mRNA is highly expressed in chronic ulcer epithelium, the translated protein is absent, suggesting the defects in translation or rapid degradation of mRNA $[3,5]$. Moreover, LL-37 antibodies were demonstrated to prevent re-epithelialization in an ex vivo human wound healing model [6]. Thus, hCAP18/lL-37 contributes to the biological process of wound healing. Experimental murine models showed that LL-37 could enhance the wound healing process, although the results showed inconsistencies $[7,8]$. The efficacy of topical administration of LL-37 in stimulating wound healing of venous leg ulcers was demonstrated previously [9].

Previous studies that used LL-37 in solution form as the vehicle showed its excellent effectivity. However, pharmaceuticals in solution preparation do not stay on the wound bed and require frequent administration $[9,10]$. Cream $(0 / \mathrm{W}$ emulsion) may stay for an extended period on the wound bed and is more practical for home use. Studies regarding the preparation of LL-37 in the cream have not been explored yet, including its stability. Accordingly, the present study aimed to prepare and investigate the stability of cream containing LL37 , which could be a novel alternative vehicle of LL-37.

\section{MATERIALS AND METHODS}

\section{Materials}

A pharmaceutical-grade chemical was used for cream preparation (Brataco, Indonesia). The active material, LL-37 (purity>95\%), was purchased from Isca Biochemicals (Exeter, UK). The chemicals used for analysis, such as methanol, acetonitrile, and trifluoroacetic acid (TFA), were of chromatographic grade (Merck, Germany), whereas distilled water was obtained from PT. Ikapharmindo Putramas, Indonesia. For the cream stability test experiment, the stability testing chamber (Nuve, TK 120, Turkey) was used. The liquid chromatographic analysis was conducted using an LC 20AD HPLC system and a pump (Shimadzu, Japan), provided with SPD-M20A photodiode array (Shimadzu, Japan), a manual injector (Rheodyne, USA), and XBridge, BEH 300, C18 column $(5 \mu \mathrm{m} \times 250 \mathrm{~mm} \times 4.6 \mathrm{~mm}$; Waters, USA). Shimadzu LC Solution $1.24 \mathrm{SP} 2$ was operated to process and evaluate the data.

\section{Methods}

\section{Cream preparation}

Table 1 displays the composition of the cream base (O/W emulsions). A heated solution consisting of glycerin and distilled water was added to the heated mixture of stearic acid, cetyl alcohol, triethanolamine, and liquid paraffin. The resulting mixture was homogenized using an automatic stirrer for $15 \mathrm{~min}$ at $3000 \mathrm{rpm}$. The acidity of the emulsion was measured and adjusted to $\mathrm{pH} 6.28$ by the addition of citric acid. Finally, a solution of LL-37 in distilled water was added to the emulsion and homogenized. The final emulsion contained $0.5 \mathrm{mg} / \mathrm{ml} \mathrm{LL}-37$.

Table 1: Compositions of cream base

\begin{tabular}{ll}
\hline Ingredients & Formulation (\%) \\
\hline Stearic acid & 7 \\
Cetyl alcohol & 2 \\
Triethanolamine & 0.5 \\
Liquid paraffin & 20 \\
Glycerin & 10 \\
Distilled water & 59.5 \\
\hline
\end{tabular}

High-performance liquid chromatography (HPLC)

Preparation of standard solution

LL-37 $10 \mathrm{mg}$ was dissolved in $10 \mathrm{ml}$ mobile phase, and the resultant solution was diluted by a similar solvent to obtain a concentration of $0.5 \mathrm{mg} / \mathrm{ml}$. 


\section{Preparation of sample solutions}

One gram of LL-37 emulsion was dissolved in $10 \mathrm{ml}$ mobile phase, sonicated for $10 \mathrm{~min}$, and then filtered using a $0.45 \mu \mathrm{m}$ membrane filter.

\section{Chromatographic conditions}

The chromatographic conditions were accomplished as per a former report [11] to optimize the ratio of mobile phase compositions. A mixture of $0.1 \%$ TFA solution in water (A) and $0.1 \%$ TFA solution in acetonitrile (B) was applied as a mobile phase with a flow rate of 1 $\mathrm{ml} / \mathrm{min}$. The SPD-M20A photodiode array was operated at $228 \mathrm{~nm}$ for the identification and quantification of the analyte. Chromatographic analysis was performed at ambient temperature and $20 \mu \mathrm{l}$ volume injection and running time of $10 \mathrm{~min}$.

\section{Method validation}

Method validation was conducted following the Association of Official Analytical Chemists (AOAC) and International Conference on Harmonization (ICH) guidelines for specificity, linearity, the limit of detection (LOD), the limit of quantitation (LOQ), accuracy, and precision $[12,13]$.

\section{Specificity}

Specificity was tested by analyzing the solvent, mobile phase, cream base, LL-37 emulsion $(0.5 \mathrm{mg} / \mathrm{ml})$, and standard solution of LL-37 $(0.5 \mathrm{mg} / \mathrm{ml})$. Related peaks were examined for retention times and peak interference.

\section{Linearity, LOD, and LOQ}

Five separate concentrations were prepared $(0.1,0.25,0.5,0.75$, and $1 \mathrm{mg} / \mathrm{ml}$ ) to evaluate the linearity of the method. The analysis of a single injection from a respective concentration was performed correspondingly. A calibration curve was then constructed from the data, and the correlation coefficient was determined. The LOD and
LOQ of LL-37 obtained using this method were derived from the calibration curve using statistical analysis $[12,13]$

\section{Accuracy and precision}

The method's accuracy and precision were determined at three different spiked concentration levels $(80 \%, 100 \%$, and $120 \%)$ adjacent to the test concentration (LL-37 $0.5 \mathrm{mg} / \mathrm{ml}$ ) by nine determinations (three replicates were prepared using the respective concentrations). The percentage recovery and relative standard deviation (RSD) were estimated for every replicate sample to evaluate accuracy and precision.

\section{Stability test}

The stability test was conducted using an accelerated stability test method to explore the effect of storage regarding the emulsion's chemical and physical substances $[14,15]$. The tests were conducted on samples stored in the stability testing chamber at $4{ }^{\circ} \mathrm{C} \pm 2{ }^{\circ} \mathrm{C}, 28$ ${ }^{\circ} \mathrm{C} \pm 2{ }^{\circ} \mathrm{C}$, and $40{ }^{\circ} \mathrm{C} \pm 2{ }^{\circ} \mathrm{C}$ at $75 \%$ room humidity. Alterations of liquefaction, color, odor and phase separation were recorded every two weeks, with a total of $12 \mathrm{w}$. The emulsion $\mathrm{pH}$ was determined using a digital $\mathrm{pH}$ meter every two weeks of storage. The concentration of LL-37 in the cream emulsion was analyzed using HPLC at 0,4 , and $12 \mathrm{w}$.

\section{RESULTS AND DISCUSSION}

\section{Optimization and validation of HPLC method}

\section{Method optimization}

The wavelength at $228 \mathrm{~nm}$, the flow rate at $1.0 \mathrm{ml} / \mathrm{min}$, and a mixture of mobile phases A and B (85:15) were achieved for the analysis. The results of the system suitability test of the method showed that the \% RSD values for retention time and area under the curve were $0.51 \%$ and $0.14 \%$, respectively, with mean tailing factors of $1.57 \pm 0.14$. The results for $\%$ RSD and tailing factor are within the acceptance criteria (fig. 1).

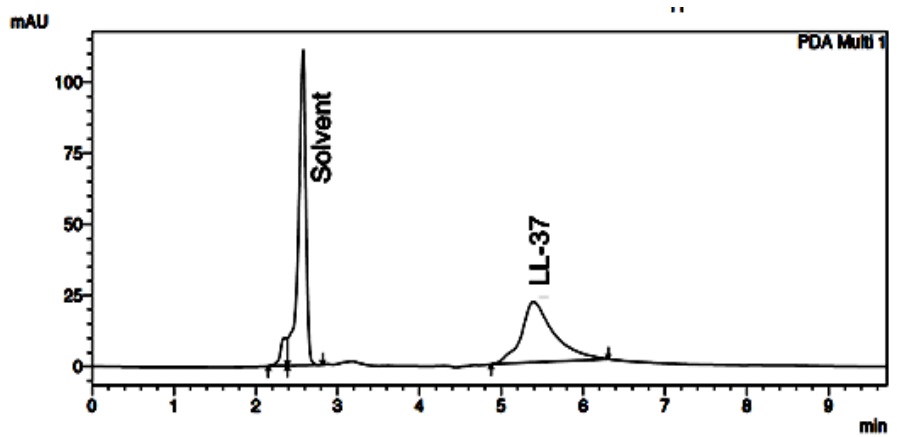

Fig. 1: Chromatogram of LL-37 standard solution

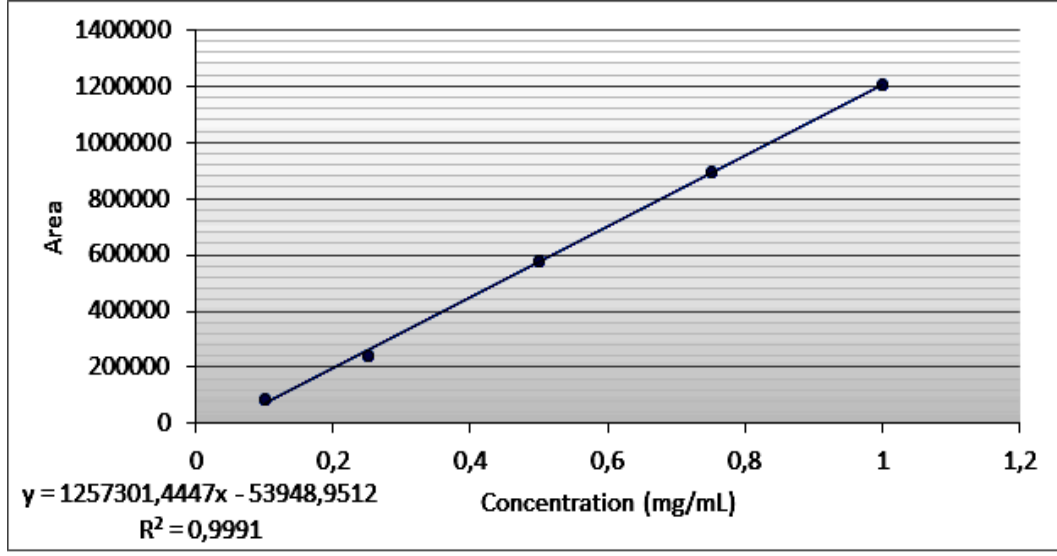

Fig. 2: Calibration curve of LL-37 
The LL-37 standard solution chromatogram, LL-37 cream, solvent, matrix, and mobile phase showed no interference on or adjacent to the LL-37 peak by solvent, matrix, or mobile phase (fig. 3), indicating the specificity of the method. To the best of our knowledge, this is the first validation study for LL-37 formulated in cream. The previous study has reported the analysis of LL-37 in polymeric gels using HPLC method, which demonstrated little to no interference. A plausible explanation could be due to the hydrophilic materials of polymers which causes an insignificant reaction with the analytical column. Given the fact that cream $(0 / W)$ is similarly hydrophilic, this could attribute to the negligible interaction of the present study [16]. The method's accuracy, which ranged from $99.28 \%$ to $101.50 \%$, was demonstrated using a \% recovery study. The precision was determined from \% RSD at concentrations of $0.4,0.5$, and $0.6 \mathrm{mg} / \mathrm{ml}$ LL-37, with values reaching $0.11 \%, 0.23 \%$, and $0.65 \%$ respectively. These results met the criteria for accuracy and precision $[12,13]$.
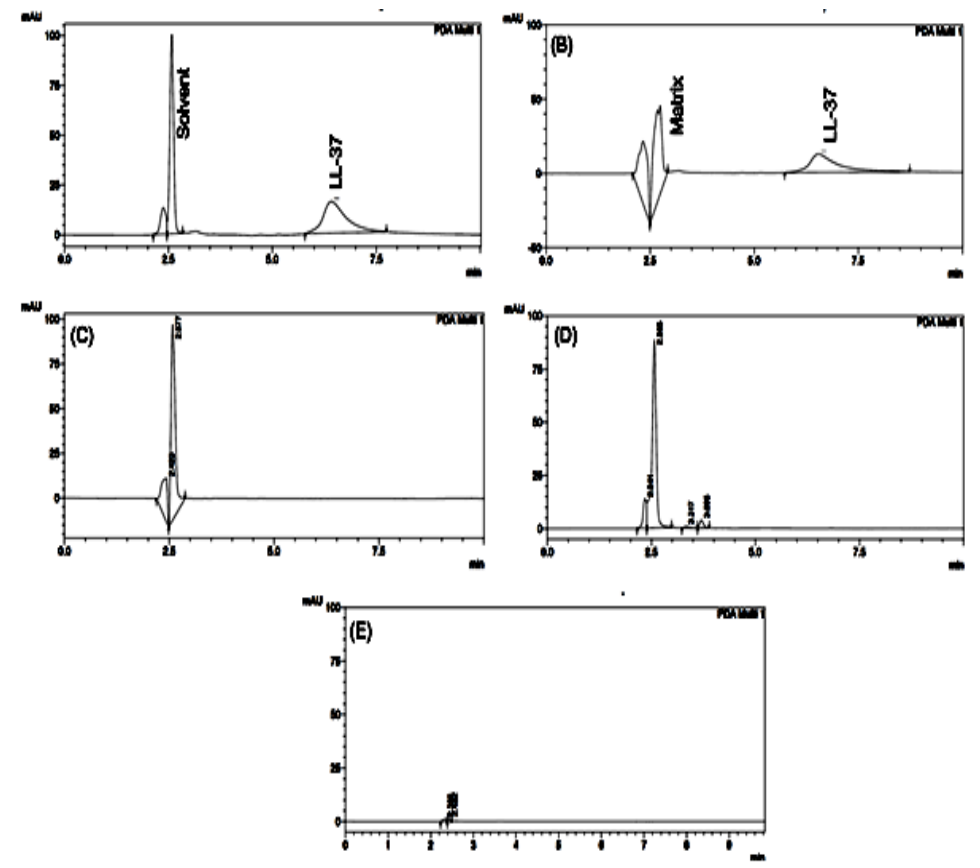

Fig. 3: Chromatogram of (A) LL-37 standard solution; (B) LL-37 cream; (C) matrix; (D) solvent; and (E) mobile phase

\section{Stability of prepared cream}

Table 2 demonstrates the alterations of liquefaction, color, and odor. The results showed white emulsions after preparation. No colour changes was detected at different storing temperatures $\left(4^{\circ} \mathrm{C}, 28^{\circ} \mathrm{C}\right.$, and $40^{\circ} \mathrm{C}$ ) up to $12 \mathrm{w}$ of observation. The increment in temperature and time influenced the separation of emulsion, which reduced viscosity and resulted in liquefaction. In this study, the liquefaction of emulsions was absent at $4{ }^{\circ} \mathrm{C}$ and $28 \pm 2{ }^{\circ} \mathrm{C}$ storage conditions during $12 \mathrm{w}$ of observation. Liquefaction was observed for the emulsion at $40 \pm{ }^{\circ} \mathrm{C}$ storage starting at week 4 , indicating the emulsion's instability as reported in another study [17]. The absence of liquefaction at $4{ }^{\circ} \mathrm{C}$ and $28{ }^{\circ} \mathrm{C}$ storage conditions demonstrated compelling support regarding this emulsion's stability under cold and room temperatures. A similar pattern of results was obtained with a study using a non-steroidal anti-inflammatory drug cream which demonstrated good physical characteristic within room temperature for 3 mo [18].

Table 2: Physical characteristics of LL-37 cream stored at $4 \pm 2{ }^{\circ} \mathrm{C}, 28 \pm 2{ }^{\circ} \mathrm{C}$, and $40 \pm 2{ }^{\circ} \mathrm{C}$

\begin{tabular}{|c|c|c|c|c|c|c|c|c|}
\hline & & Baseline & $2 w$ & $4 w$ & $6 w$ & $8 w$ & $10 w$ & $12 w$ \\
\hline \multirow[t]{3}{*}{ Liquefaction } & $4^{\circ} \mathrm{C}$ & - & - & - & - & - & - & - \\
\hline & $28^{\circ} \mathrm{C}$ & - & - & - & - & - & - & - \\
\hline & $40^{\circ} \mathrm{C}$ & - & - & + & + & + & + & + \\
\hline \multirow[t]{3}{*}{ Color } & $4{ }^{\circ} \mathrm{C}$ & - & - & - & - & - & - & - \\
\hline & $28^{\circ} \mathrm{C}$ & - & - & - & - & - & - & - \\
\hline & $40^{\circ} \mathrm{C}$ & - & - & - & - & - & - & - \\
\hline \multirow[t]{3}{*}{ Odor } & $4{ }^{\circ} \mathrm{C}$ & - & - & - & - & - & - & - \\
\hline & $28^{\circ} \mathrm{C}$ & - & - & - & - & - & - & - \\
\hline & $40^{\circ} \mathrm{C}$ & - & - & - & - & - & - & - \\
\hline
\end{tabular}

-= Negative/no change; $+=$ Positive

The alteration of $\mathrm{pH}$ implies the consequence of chemical reactions, providing insights into the outcome's quality. The ideal pH of human skin varies from 4.5 to 6.0 . LL-37 cream preparation should have a $\mathrm{pH}$ that is close or within this range to exert its optimal function and possibly gain regulatory approval. The emulsions prepared in this study yielded a $\mathrm{pH}$ of 6.28 , close to the $\mathrm{pH}$ of natural skin. Furthermore, storing the emulsion samples at different temperatures $\left(4^{\circ} \mathrm{C}, 28{ }^{\circ} \mathrm{C}\right.$, and $\left.40^{\circ} \mathrm{C}\right)$ may continually reduce the $\mathrm{pH}$ during the $12 \mathrm{w}$ of observation. Destabilization of the emulsion through hydrolysis occurred during storage at elevated temperatures [13]. These findings are in line with a previous study using an anti-wrinkle cream which demonstrated that higher temperatures resulted in increased viscosity [19]. As evidenced in this study, storing the emulsions at $4{ }^{\circ} \mathrm{C}, 28^{\circ} \mathrm{C}$, and $40{ }^{\circ} \mathrm{C}$ resulted in an acceptably stable $\mathrm{pH}$ at nearly 6.0 , which is tolerable and gentle to the skin. 
The concentration of LL-37 in cream preparation during the $12 \mathrm{w}$ of storage at various temperatures showed minimal degradation (table 3 , fig. 4). Linear regression analysis between the ln concentrations of
LL-37 at $4{ }^{\circ} \mathrm{C}, 28{ }^{\circ} \mathrm{C}$, and $40{ }^{\circ} \mathrm{C}$ against time indicated that the degradation periods needed by the compound to reach $90 \%$ of the initial concentration were 99,75 , and 16 mo, respectively.

Table 3: LL-37 concentration at various temperatures during $12 \mathrm{w}$ of observation

\begin{tabular}{llll}
\hline Storage condition & \multicolumn{3}{l}{ Mean LL-37 concentration (mg/ml) } \\
\cline { 2 - 4 } & Baseline & $\mathbf{4} \mathbf{~ w}$ & $\mathbf{1 2} \mathbf{~ w}$ \\
\hline $4^{\circ} \mathrm{C}$ & 0.492 & 0.491 & 0.491 \\
$28{ }^{\circ} \mathrm{C}$ & 0.493 & 0.492 & 0.491 \\
$40^{\circ} \mathrm{C}$ & 0.512 & 0.508 & 0.500 \\
\hline
\end{tabular}

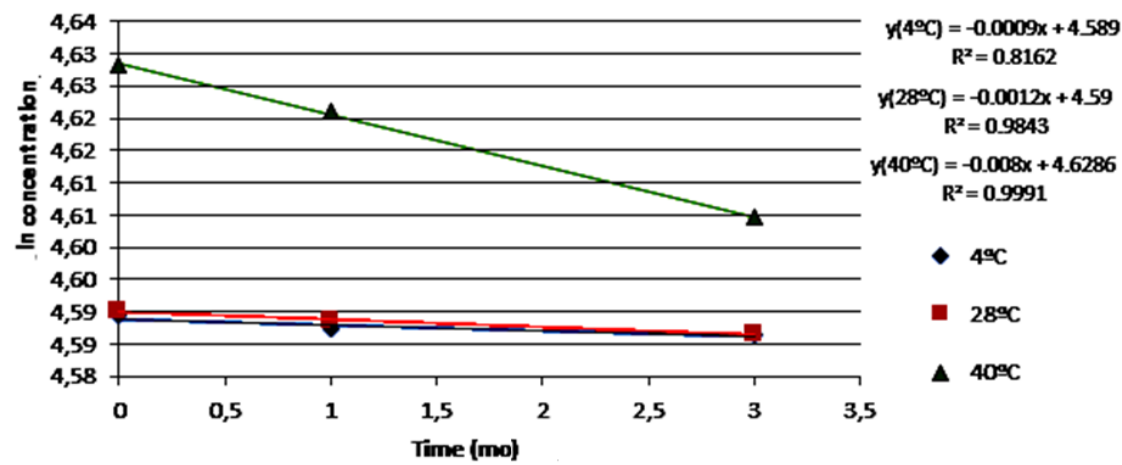

Fig. 4: Linear regression graph of LL-37 stability

\section{CONCLUSION}

The preparation and stability study of LL-37 cream has been conducted successfully. Quantitation of LL-37 in cream $(0 / W$ emulsion) could be achieved through this HPLC method. Our findings indicate that LL-37 cream ( $0 / \mathrm{W}$ emulsion) establishes good physical characteristics and stabilizes the active ingredient, especially at $4{ }^{\circ} \mathrm{C}$ and $28^{\circ} \mathrm{C}$ storage. Therefore, the emulsion delivery system is harmless and stable.

\section{ACKNOWLEDGEMENT}

The authors would like to express gratitude to the Directorate of Research and Community Engagements Universitas Indonesia for the research grant Tugas Akhir Dosen (TADOK) 2019.

\section{FUNDING}

Nil

\section{AUTHORS CONTRIBUTIONS}

All authors have contributed equally.

\section{CONFLICTS OF INTERESTS}

The authors declare no conflict of interest.

\section{REFERENCES}

1. Cho NH, Shaw JE, Karuranga S, Huang Y, da Rocha Fernandes JD, Ohlrogge AW, Malanda B. IDF Diabetes Atlas: global estimates of diabetes prevalence for 2017 and projections for 2045. Diabetes Res Clin Pract. 2018;138:271-81. doi: 10.1016/j.diabres.2018.02.023, PMID 29496507.

2. Alavi A, Sibbald RG, Mayer D, Goodman L, Botros M, Armstrong DG, Woo K, Boeni T, Ayello EA, Kirsner RS. Diabetic foot ulcers: Part II. Management. J Am Acad Dermatol. 2014;70(1):21.e124; quiz 45. doi: 10.1016/j.jaad.2013.07.048, PMID 24355276.

3. Mohd KS, Hassan MA, Azemin W, Dharmaraj S. A review of potential anticancers from antimicrobial peptides. Int J Pharm Pharm Sci. 2014;7:19-26.

4. Frohm Nilsson MF, Sandstedt B, Sørensen 0, Weber G, Borregaard N, Stahle-Backdahl M. The human cationic antimicrobial protein (hCAP18), a peptide antibiotic, is widely expressed in human squamous epithelia and colocalizes with interleukin-6. Infect Immun. 1999;67(5):2561-6. doi 10.1128/IAI.67.5.2561-2566.1999, PMID 10225921.

5. Dean SN, Bishop BM, van Hoek ML. Natural and synthetic cathelicidin peptides with anti-microbial and anti-biofilm activity against Staphylococcus aureus. BMC Microbiol. 2011;11:114. doi: 10.1186/1471-2180-11-114, PMID 21605457.

6. Heilborn JD, Nilsson MF, Kratz G, Weber G, Sorensen O, Borregaard N, Stahle-Backdahl M. The cathelicidin antimicrobial peptide LL-37 is involved in re-epithelialization of human skin wounds and is lacking in chronic ulcer epithelium. J Invest Dermatol. 2003;120(3):379-89. doi: 10.1046/j.15231747.2003.12069.x, PMID 12603850.

7. Ramos R, Silva JP, Rodrigues AC, Costa R, Guardão L, Schmitt F, Soares R, Vilanova M, Domingues L, Gama M. Wound healing activity of the human antimicrobial peptide LL37. Peptides. 2011;32(7):1469-76. doi: 10.1016/j.peptides.2011.06.005, PMID 21693141

8. Steinstraesser L, Ring A, Bals R, Steinau HU, Langer S. The human host defense peptide LL37/hCAP accelerates angiogenesis in PEGT/PBT biopolymers. Ann Plast Surg. 2006;56(1):93-8. doi: 10.1097/01.sap.0000190883.30005.91, PMID 16374104.

9. Grönberg A, Mahlapuu M, Ståhle M, Whately-Smith C, Rollman 0 . Treatment with LL-37 is safe and effective in enhancing healing of hard-to-heal venous leg ulcers: a randomized, placebo-controlled clinical trial. Wound Repair Regen. 2014;22(5):613-21. doi: 10.1111/wrr.12211, PMID 25041740.

10. Grönberg A, Zettergren L, Agren MS. Stability of the cathelicidin peptide LL-37 in a non-healing wound environment. Acta Derm Venereol. 2011;91(5):511-5. doi: 10.2340/00015555-1102, PMID 21547341.

11. Krahulec J, Hyrsova M, Pepeliaev S, Jilkova J, Cerny Z, Machalkova J. High-level expression and purification of antimicrobial human cathelicidin LL-37 in Escherichia coli. Appl Microbiol Biotechnol. 2010;88(1):167-75. doi: 10.1007/s00253-010-2736-7, PMID 20625720.

12. Association of Official Agricultural Chemists. Official methods of analysis. 16th ed. Rockville: AOAC; 2002.

13. International Conference of Harmonisation. Validation of analytical procedures: text and methodology. Vol. Q2. Switzerland: ICH; 2005. p. R1. 
14. Grimm W. Stability testing of clinical trial materials. In: Rhodes CT, Carstensen JT, editors. Drugs and the pharmaceutical sciences. 3rd ed. rev and expanded ed. New York: Marcel Dekker; 2000.

15. Hong DD, Shah M. Development and validation of HPLC stability-indicating assays. In: Rhodes CT, Carstensen JT, editors. Drugs and the pharmaceutical sciences. 3rd ed, rev and expanded ed. New York: Marcel Dekker; 2000.

16. Chen Y, Yang S, Ho EA. Development of an analytical method for the rapid quantitation of peptides used in microbicide formulations. Chromatographia. 2014;77(23-24):1713-20. doi: 10.1007/s10337-014-2777-7, PMID 25477555.
17. Smaoui S, Ben Hlima H, Ben Chobba I, Kadri A. Development and stability studies of sunscreen cream formulations containing three photo-protective filters. Arab J Chem. 2017;10:S1216-22. doi: 10.1016/j.arabjc.2013.02.020.

18. Anwar S, Jan SU, Gul R. Formulation and evaluation of celecoxib cream and its released study. Int J Curr Pharm Sci. 2020;12:159. doi: 10.22159/ijcpr.2020v12i5.39757.

19. Sirisa Ard P, Peerakam N, Huy NQ, On TV, Long PT, Intharuksa A. Development of anti-wrinkle cream from Pueraria candolle var. mirifica (airy shaw and suvat.) niyomdham, "Kwao krua kao" for menopausal women. Int J Pharm Pharm Sci. 2018;10(7):16-21. doi: 10.22159/ijpps.2018v10i7.24665. 